\title{
Effect of Plumeria rubra (Apocynaceae) leaf extracts, a repellent of rice-field rats (Rattus argentiventer), on its metabolism and daily activity
}

\author{
Ichsan Nurul Bari ${ }^{1 *}$, Nur'aini Herawati ${ }^{2}$, Bunga Medina Suherman ${ }^{1}$ \\ \& Syifa Nabilah Subakti Putri ${ }^{1}$ \\ 1. Pest Laboratory, Vertebrae Sub-division, Department of Pest and Plant Disease, Faculty of Agriculture, Universitas \\ Padjadjaran, Sumedang 45363, West Java, Indonesia; ichsan@unpad.ac.id, bungamedinas@yahoo.com, \\ syifa.nsp96@gmail.com \\ 2. Indonesian Center for Rice Reseach, Jalan Raya 9, Sukamandi, Subang 41256, Indonesia; \\ nherawati.yuwono@gmail.com \\ * Correspondence
}

Received 29-II-2020. Corrected 06-VIII-2020. Accepted 11-IX-2020.

\begin{abstract}
Introduction: Rice-field rats are one of the most important pests because it can give large losses in all planting seasons including the storehouse. Synthetic rodenticide is the most commonly used of chemical technique for controlling rice-field rats. The application of these materials indirectly causes negative impacts; one of them is for the environment. As an alternative for controlling rice-field rats, natural materials can be used as a repellent. Objective: to examine the effects of methanol extract of Plumeria rubra leaves on metabolism, daily activity patterns, and its potency as a repellent of the rice-field rat. Methods: The experiments were conducted at the Laboratory of Pests, Universitas Padjadjaran involves choice test (T-maze arena), and the Laboratory of Rats, Indonesian Center for Rice Research involves no-choice test (metabolic cage) from February until May 2019. The observations including food (g), water consumption (ml), feces production $(\mathrm{g})$, urine production $(\mathrm{ml})$, body weight $(\mathrm{g})$, and its changes $(\%)$, also the daily activities (time spent for locomotion, foraging, and resting). The treatment was done with three replications for twelve mature male and twelve mature non-pregnant females. Data experiments analysis followed by a T-test. Results: Rice-field rats on the T-Maze arena avoided consuming food and beverage that close to methanol extract of Plumeria rubra leaves treatment. The treatment of methanol extract of Plumeria leaves in metabolic cage caused metabolic disorder of rice-field rat, which was significantly indicated by the decrease of the average consumption of food by $2.28 \mathrm{~g}$ and excretion of feces by $0.34 \mathrm{~g}$, and also the increase of average consumption of beverage by $3.89 \mathrm{ml}$, excretion of urine by $3.15 \mathrm{ml}$, and body weight by $6.67 \mathrm{~g}$. The treatment also caused daily activity patterns disorder of rice-field rats, which was significantly indicated by the increase of the average percentage of time for movement activities (locomotion) by $7.64 \%$ and the decrease of time for eating and drinking activities (foraging) by $16.46 \%$. Conclusion: Methanol extract of Plumeria leaves affects a repellent for the rice-field rat.
\end{abstract}

Key words: secondary-metabolites; chemical control; vertebrates; Apocynaceae; choice-test.

Bari, I.N., Herawati, N., Medina Suherman, B., \& Subakti Putri, S.N. (2020). Effect of Plumeria rubra (Apocynaceae) leaf extracts, a repellent of rice-field rats (Rattus argentiventer), on its metabolism and daily activity. Revista de Biología Tropical, 68(4), 1357-1370.

Rice-field rat (Rattus argentiventer) is one of the most important pests throughout the world. Rats can impact throughout cropping from seedling to harvesting stage, continues to post-harvest process in the storehouse (Priyambodo, 2009). Present chemical control for rodent pest species focuses mostly by using synthetic rodenticides. This technique is the most 
effective method and widely used to control rice-field rats (Sudarmaji, 2018). The rodenticides can also have undesirable side effects for non-target species and can also pollute the environment (Brown, Leung, Sudarmaji, \& Singleton, 2003). Repellent, as an alternative chemical control of rice-field rats, can be less toxic and less harmful to the environment than rodenticides. The repellent application strategies by using effective chemical repellent are required to protect the resources from the damages caused by vertebrates (Werner, De Liberto, Baldwin, \& Witmer, 2016). There have been many studies about plant secondary metabolites (PSMs) produce by several plant species that have potential as rodent repellents. Laboratory studies revealed that various groups of compounds, including essential oils and terpenoids, alkaloids, alkylamides, (di) carboxylic acids, glucosinolates, and phenolic, have been considered as a rodent repellent regarding by animal behavior/metabolism (Hansen, Stolter, Imholt, \& Jacob, 2016).

Frangipani (Plumeria rubra), native to tropical America and belongs to the Apocynaceae family (Criley, 2005), has secondary metabolites in its several parts, one of them is in leaves. The methanol extract of frangipani leaves contains tannin, phlobatannin, saponin, flavonoid, steroid, terpenoids, cardiac glycoside, reducing sugar (Manisha \& Aher, 2016), and also alkaloids (Utami, 2017). Frangipani has been reported in many studies as a plantderived repellent for several insect species. Ramos, Araújo, Oliveira, Teixeira, and Pereira (2011) have previously reported that the sap of frangipani leaves has the potential as a repellent for beetle (Callosobruchus maculatus) and leaf beetle (Zabrotis subfasciatus). Muthusamy (2014) also reported that the flowers of frangipani were found to have the potential as a repellent for mosquito (Aedes aegypti). The information about the potency of this species as plant-derived rodent repellents is unknown. The present study investigated the effects of methanol extract of frangipani leaves on metabolism, daily activity patterns, and its potency as a repellent of male and female ricefield rats.

\section{MATERIALS AND METHODS}

Study site: The experiments were conducted at Laboratory of Pests, Division of Pests Vertebrate, Department of Plant Pests and Diseases, Faculty of Agriculture, Universitas Padjadjaran $\left(6^{\circ} 35^{\prime} 32.72\right.$ ' S \& 10764'55.73” E) and Laboratory of Rats, Indonesian Center for Rice Research (655'33.0" S \& 10746'24.6" E), from February until May 2019.

Plant material: Young leaves were collected from along the roadside Moh, Toha highway, Bandung, West Java, Indonesia. The collected leaves were washed with tap water, air-dried for 2 weeks, and mashed with a blender into a powder for about $100 \mathrm{~g}$.

Extraction and distillation: Powdered plant material $(100 \mathrm{~g})$ was subjected to $48 \mathrm{~h}$ extraction with $1000 \mathrm{ml}$ of $70 \%$ methanol $(\mathrm{MeOH})$. The ratio of plant materials and solvents were $(1: 10)$. The process of extraction (maceration) was practiced a $1 \mathrm{~L}$ beaker glass, covered with cling-wrap plastic film and aluminum foil, held in place with a rubber band. After the first $24 \mathrm{~h}$, the crude extract was stirred with a spatula. The crude extract was filtered using a filter paper at the end of $48 \mathrm{~h}$ extraction. The distillation of crude extract after the extraction process was using automatic steam distillation $\left( \pm 80^{\circ} \mathrm{C}\right)$ for about $1.5-2 \mathrm{~h}$. The result of the distillation process was $600 \mathrm{ml}$ methanol extract of frangipani leaves in a liquid form. The extract was stored inside the refrigerator $\left( \pm 2{ }^{\circ} \mathrm{C}\right)$ until used for the experiment.

Rice-field rat: The animals were initially supplied by the Indonesian Center for Rice Research (ICRR). Beforehand, it was collected originally from the closest rice-fields from ICRR by implementing LTBS (Linear Trap Barrier System). Healthy and mature 12 males $(\circlearrowleft)$ and 12 females not pregnant $(+$ ) r ricefield rats with a range body weight between 
90-130 g were chosen. The animal test was individually kept in aluminum-framed cages, adapted with food (brown rice) and beverage (tap water) under laboratory conditions for 7 days. Bodyweight changes and consumption of food and beverage of each animal test were daily measured for standard data.

Choice test: The effect of methanol extract of frangipani leaves for the choice test was observed by using the T-maze arena (Fig. 1) at the Laboratory of Rats, Indonesian Center for Rice Research. The arena of T-maze has 2 goals, left hand (A) was a treatment room with methanol extract of frangipani leaves and right hand (B) was a control room without methanol extract of frangipani leaves. The extract was sprayed onto 2 cloth sheets $(10 \times 10 \mathrm{~cm})$ with a hand sprayer $(5 \mathrm{ml} / \mathrm{sheet})$ and placed inside room treatment (A) that close to food and beverage containers. Rice-field rat was individually kept in the T-maze arena, provided with food (brown rice $10 \%$ of body weight) and beverage (100 $\mathrm{ml}$ of water), at the same amount both in the left hand and right hand of the T-maze arena, every day in the afternoon for 6 days experiment. The observations were carried out every day in the morning, including food consumption $(\mathrm{g})$, water consumption $(\mathrm{ml})$, bodyweight (g) and its changes (\%).

No-choice test: The effect of methanol extract of frangipani leaves for the no-choice test was observed by using metabolic cage (Fig. 2) at the Laboratory of Pests, Division of Pests Vertebrate, Department of Plant Pests and Diseases, Faculty of Agriculture, Universitas Padjadjaran. The extract was sprayed onto 2 cloth sheets $(4 \times 8 \mathrm{~cm})$ with a hand sprayer $(5$ $\mathrm{ml} / \mathrm{sheet}$ ) and placed close to food and beverage containers. Rice-field rat was individually kept in a metabolic cage, provided with food (brown rice $10 \%$ of body weight) and beverage $(100 \mathrm{ml}$ of water) every day in the afternoon for 6 days experiment. The observations for metabolic effects were carried out every day in the morning, including food consumption $(\mathrm{g})$, water consumption $(\mathrm{ml})$, feces production $(\mathrm{g})$, urine production $(\mathrm{ml})$, body weight $(\mathrm{g})$ and its changes (\%). Moreover, the daily activities of rice-field rats also observed coincide, including time spent for movement activities (locomotion), eating and drinking activities (foraging), and resting and sleeping activities (resting). The daily activities were observed by CCTV (Closed Circuit Television) and measured for

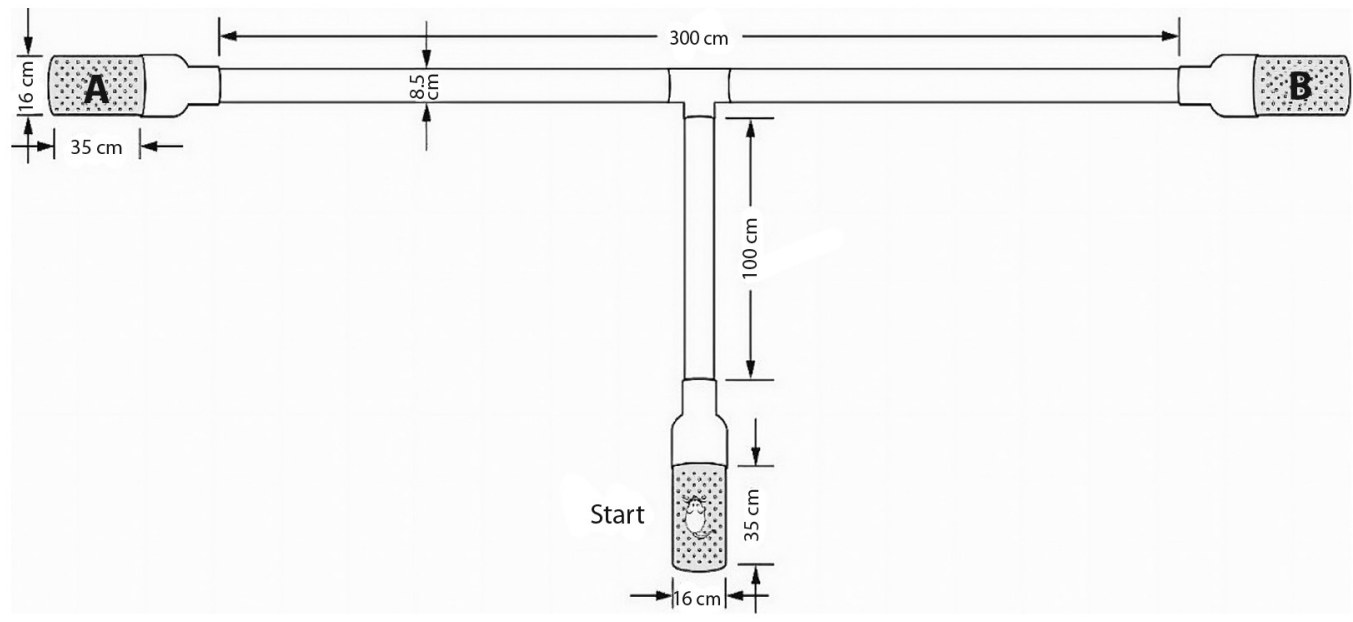

Fig. 1. The scheme of T-Maze arena. The arena has 3 sections: one start and two goals. A. Without methanol extract of frangipani leaves and $\mathbf{B}$. with methanol extract of frangipani leaves. 

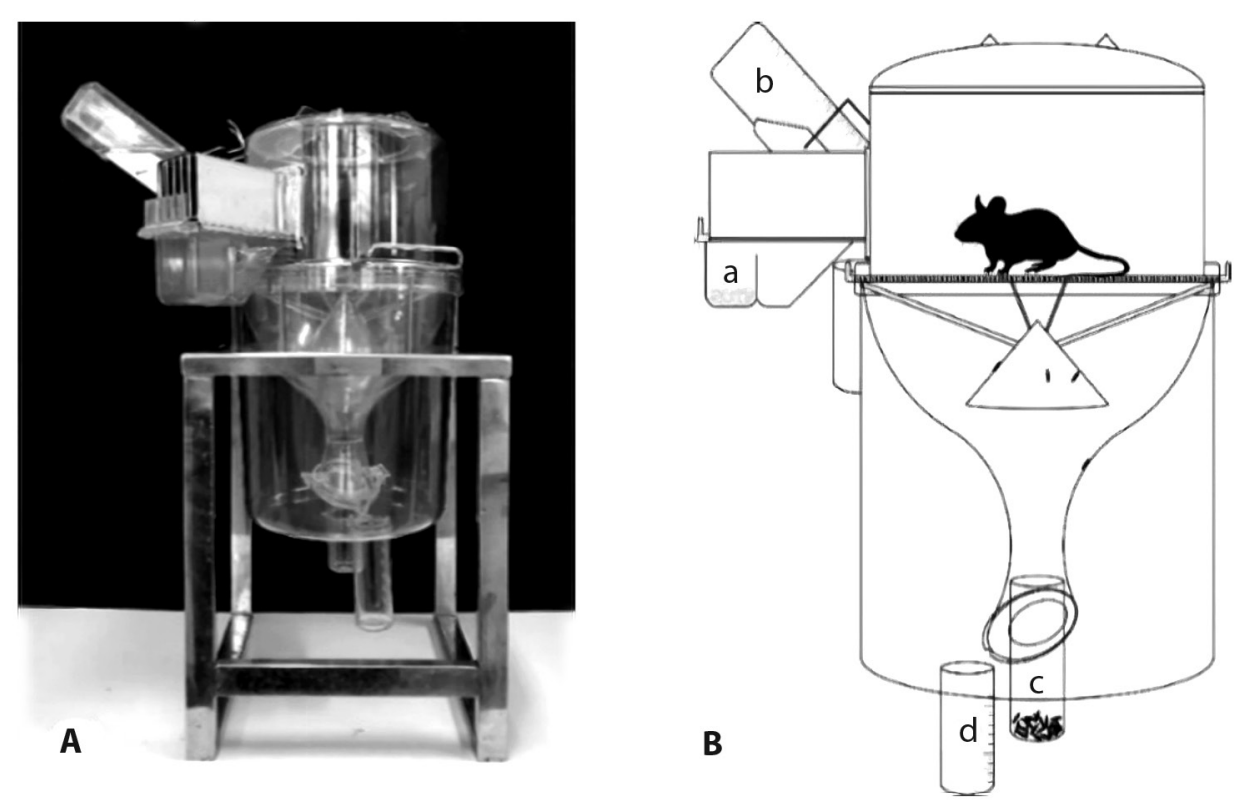

Fig. 2. Metabolic cages: A. Nalgene metabolic cage and B. the scheme of Nalgene metabolic cage was including containers for (a) food, (b) beverage, (c) feces, and (d) urine. Data processing and analyses: The treatments were done with 3 replications for both male and female rice-field rats, respectively. Data experiments from each treatment in the choice and no-choice test were analyzed using The IBM SPSS ${ }^{\circledR}$ software ver. 24.0 for Windows. When requirements for normality of data and homogeneity of variance were satisfied, the analysis followed by Student's t-test for independent (unpaired) samples (Independent Sample T-test) or paired samples (Paired Sample T-test), assessed at $95 \%$ confidence level to compare the differences between treatment means.

12 hours $(18: 00 \mathrm{~h}-06: 00 \mathrm{~h})$ to avoid disturbances on the animal test.

\section{RESULTS}

Daily food and water consumption in the T-maze arena: The result showed that the food and water placed inside the control room (B) were highly significantly consumed than inside the treatment room (A). The average daily food and water consumption of male and female rice-field rats in the T-maze arena are summarized in Fig. 3 and Fig. 4, respectively.

Body weight and its changes in the T-maze arena: The results of body weight and its changes in male and female rice-field rats in T-maze are shown in Table 1. This study showed that there was a body weight decrease on average. During the experiment, the average body weight loss in male and female ricefield rats was $6.00 \mathrm{~g}$ about $5.13 \%$, and 8.66 $\mathrm{g}$ about $8.08 \%$, respectively. Based on the results of statistical analysis, the Paired Sample T-test on the average body weight changes of male and female rice-field rats in the T-maze arena, showed that the treatment of methanol extract of frangipani leaves has no significantly reduced body weight of male rice-field rats $(\mathrm{P}$ $>0.05)$. Otherwise, the same treatments have significantly reduced the bodyweight of female rice-field rats $(\mathrm{P}<0.05)$. The optimal temperature and humidity for rats ranged from 24-26 ${ }^{\circ} \mathrm{C}$ and 40-70\%. However, the average temperature and humidity were higher during the experiment at Laboratory of Rats; Indonesian Center for Rice Research was $30.0^{\circ} \mathrm{C}$ and 75.3 $\%$, respectively.

Daily food and water consumption in the metabolic cage: The laboratory study 

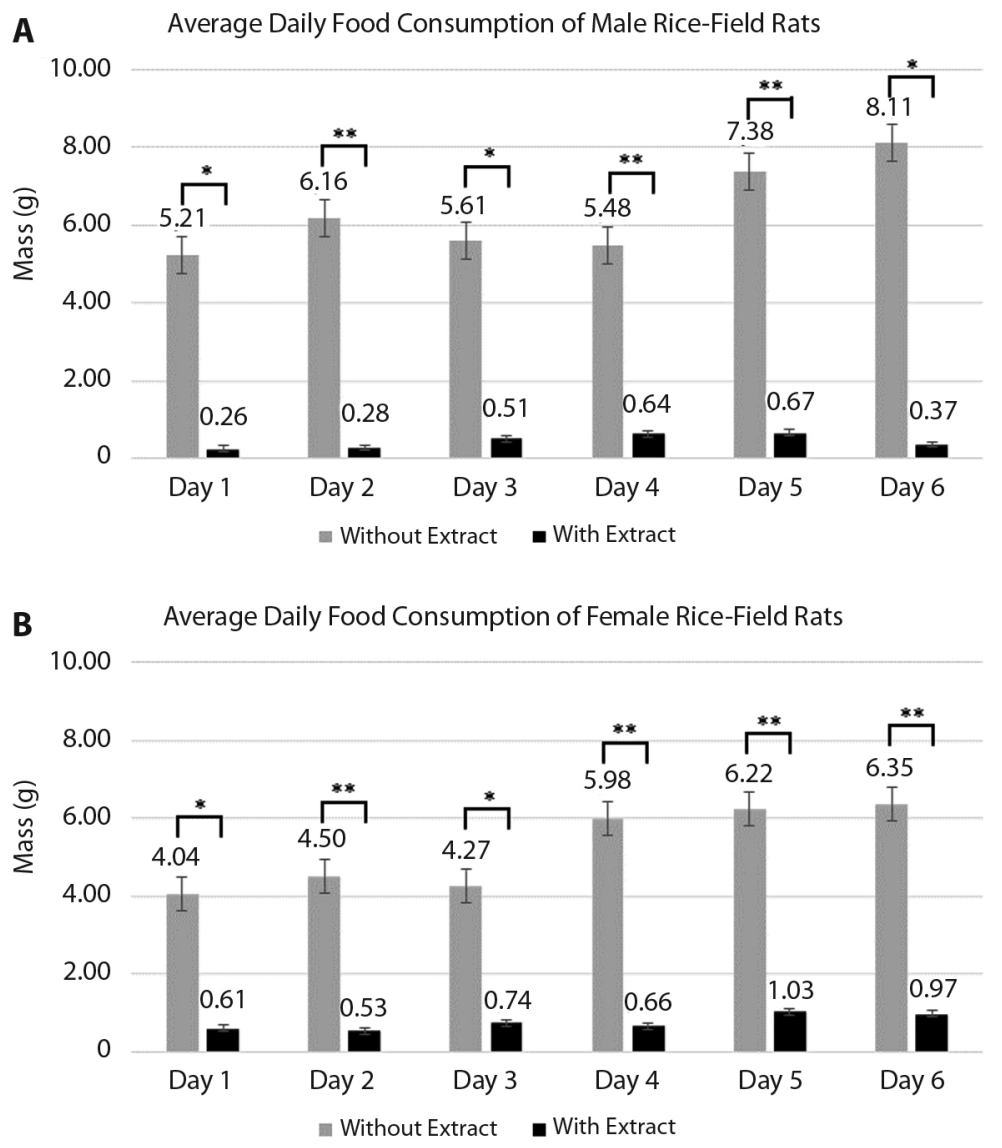

Fig. 3. Average daily food consumption of male A. and female B. rice-field rats, every day until six days of observation in the T-maze arena. Treatments were including with and without methanol extract of Plumeria rubra leaves. The standard error $(\mathrm{SE})$ of the mean is shown by a vertical bar. $(*)$ indicates a significant difference between treatments. $* \mathrm{P}<0.05=$ significant, ${ }^{* *} \mathrm{P}<0.001=$ highly significant, according to Independent Sample T-Test $(\alpha=0.05)$.

\section{TABLE 1}

Average body weight (before and after treatment) and body weight changes of male and female rice-field rats after six days of observation in the T-maze arena

\begin{tabular}{|c|c|c|c|c|}
\hline \multirow[b]{2}{*}{ Sex } & \multirow[b]{2}{*}{ Treatments } & \multicolumn{2}{|c|}{ Body-weight (g) } & \multirow{2}{*}{$\begin{array}{l}\text { Body-weight } \\
\text { Changes (\%) }\end{array}$} \\
\hline & & $\begin{array}{c}\text { Before } \\
\text { Treatment }\end{array}$ & $\begin{array}{l}\text { After } \\
\text { Treatment }\end{array}$ & \\
\hline Male & $\begin{array}{l}\text { With methanol extract of Plumeria rubra leaves } \\
\text { Without methanol extract of Plumeria rubra leaves }\end{array}$ & 116.67 & $110.67^{\mathrm{ns}}$ & -5.13 \\
\hline Female & $\begin{array}{l}\text { With methanol extract of Plumeria rubra leaves } \\
\text { Without methanol extract of Plumeria rubra leaves }\end{array}$ & 107.33 & $98.67^{*}$ & -8.08 \\
\hline
\end{tabular}

(*) indicate a significant difference between before and after treatment on body weight $(* \mathrm{P}<0.05=$ significant, $* * \mathrm{P}<0.001$ $=$ highly significant, according to Paired Sample T-Test $(\alpha=0.05)$. 

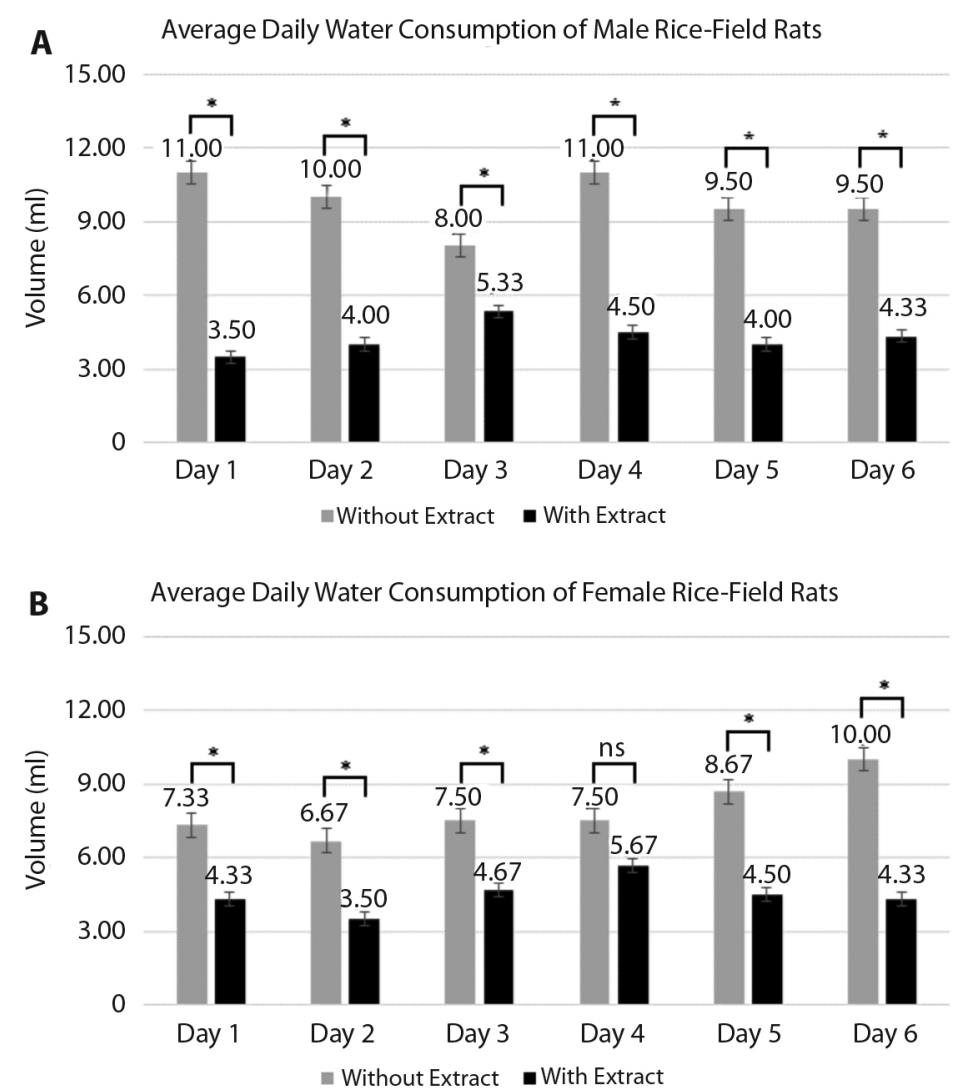

Fig. 4. Average daily water consumption of male A. and female B. rice-field rats, every day until six days observation in the T-maze arena. Treatments were including with and without methanol extract of Plumeria rubra leaves. The standard error (SE) of the mean is shown by a vertical bar. $\left(^{*}\right)$ indicates a significant difference between treatments. $* \mathrm{P}<0.05=$ significant, $* * \mathrm{P}<0.001=$ highly significant, according to Independent Sample T-Test $(\alpha=0.05)$.

revealed that both male and female rice-field rats in the metabolic cage without methanol extract (control) tended to consume highly significant of food with the range 8.63-11.26 $\mathrm{g}$ and extract frangipani leaves 5.63-8.19 g (Fig. 5). While in water consumption showed opposite results that both male and female rice-field rats tended to consume highly significant of water on extract frangipani leaf treatment with the range 9.00-12.67 $\mathrm{ml}$ than control 5.33-9.00 $\mathrm{ml}$ (Fig. 6).

Feces and urine productions in the metabolic cage: The effects of methanol extract of frangipani leaves were also found in feces and urine production of male and female ricefield rats in the metabolic cage. The study in the metabolic cage without methanol extract of frangipani leaves showed that both male and female rice-field rats produced highly significant of feces than extract proven by the difference between 0.02-0.66 g (Fig. 7). The criteria of the feces were relatively the same, including round/oval, black-brown, and dry. Otherwise, in the metabolic cage with methanol extract of frangipani leaves, both the same animal test produced highly significant of urine than other treatments (Fig. 8). On the other hand, the study in metabolic cage methanol extract of frangipani leaves showed that both male 


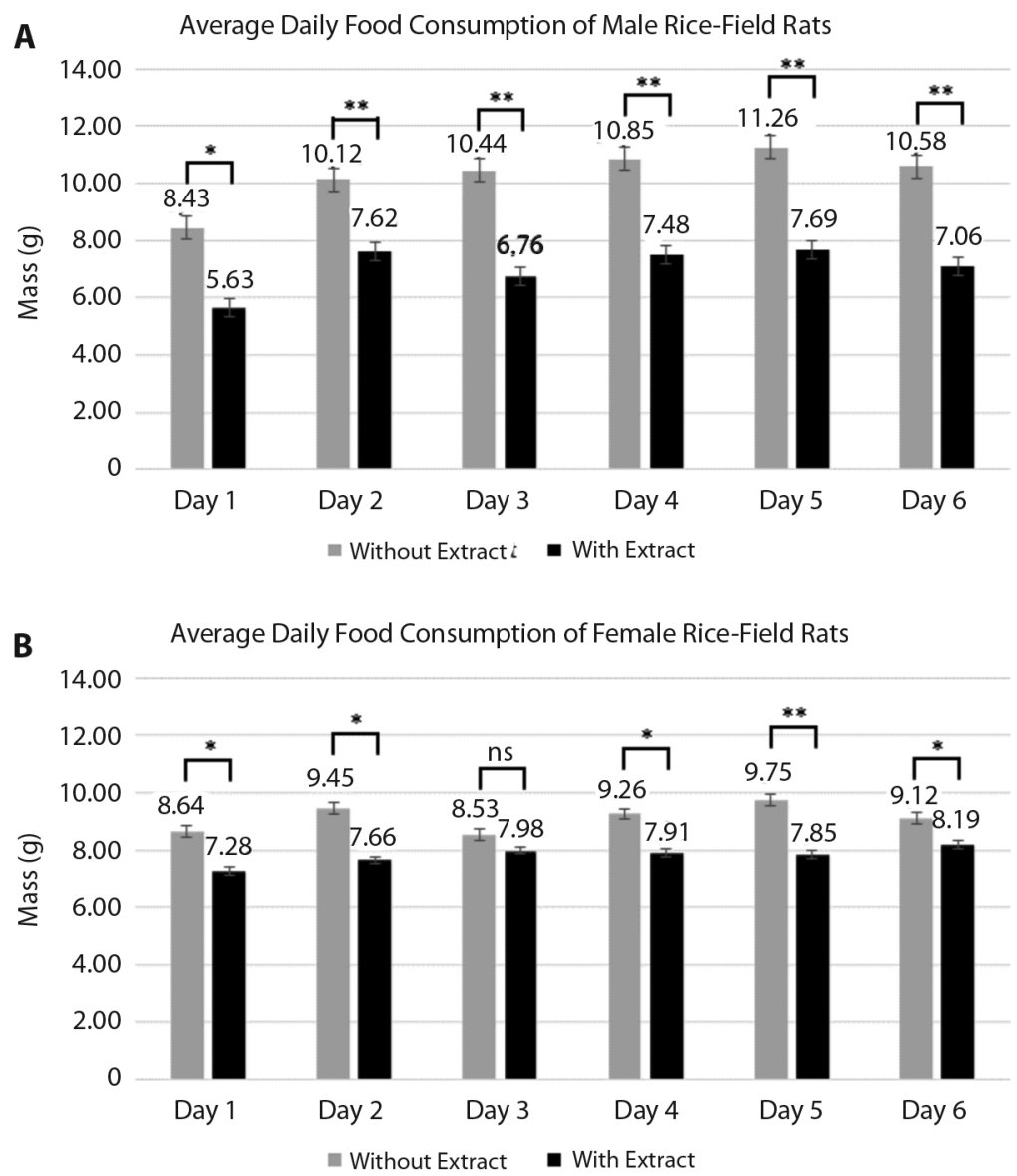

Fig. 5. Average daily food consumption of male A. and female B. rice-field rats, every day until six days of observation in the metabolic cage. Treatments were including with and without methanol extract of Plumeria rubra leaves. The standard error $(\mathrm{SE})$ of the mean is shown by a vertical bar. $(*)$ indicates a significant difference between treatments. $* \mathrm{P}<0.05=$ significant, ${ }^{* *} \mathrm{P}<0.001=$ highly significant, according to Independent Sample T-Test $(\alpha=0.05)$.

and female rice-field rats produced highly significant of urine than without extract (control) by the difference between $2.24-3.67 \mathrm{ml}$.

Body weight and its changes: Based on the body weight and its changes of male and female rice-field rats presented in Table 2, either with or without methanol extract of frangipani leaves in the metabolic cage has increased all of the animal test bodyweights. However, the body weight gain between male and female rice-field rats was quite different. The average body weight gain of male rice-field rats was higher in the metabolic cage without methanol extract of frangipani leaves (5.33 g about 5.05 $\%$ and $7.33 \mathrm{~g}$ about $6.18 \%$, respectively for each treatment), whereas on female rice-field rats the average body weight gain was higher in the metabolic cage with methanol extract of frangipani leaves $(8.00 \mathrm{~g}$ about $7.03 \%$ and $6.00 \mathrm{~g}$ about $5.46 \%$, respectively for each treatment). The results of statistical analysis, the Paired Sample T-test on the average body weight changes of male and female rice-field rats in the metabolic cage, showed that all treatments have significantly increased body weight 

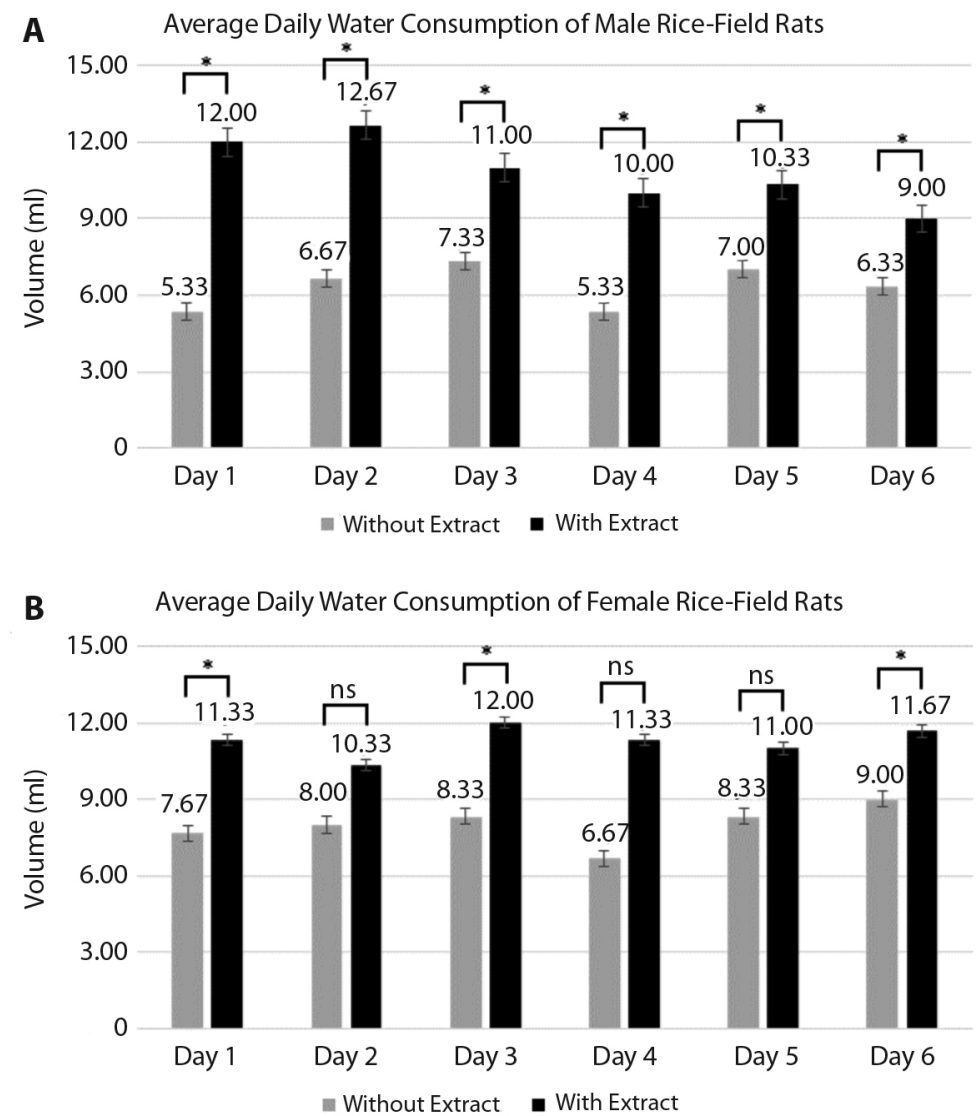

Fig. 6. Average daily water consumption of male A. and female B. rice-field rats, every day until six days of observation in the metabolic cage. Treatments were including with and without methanol extract of Plumeria rubra leaves. The standard error $(\mathrm{SE})$ of the mean is shown by a vertical bar. $(*)$ indicates a significant difference between treatments. $* \mathrm{P}<0.05=$ significant, $* * \mathrm{P}<0.001=$ highly significant, according to Independent Sample T-Test $(\alpha=0.05)$.

TABLE 2

Average body weight (before and after treatment) and body weight changes of male and female rice-field rats after six days of observation in the metabolic cage

\begin{tabular}{|c|c|c|c|c|}
\hline \multirow[b]{2}{*}{ Sex } & \multirow[b]{2}{*}{ Treatments } & \multicolumn{2}{|c|}{ Body Weight (g) } & \multirow[b]{2}{*}{$\begin{array}{l}\text { Body Weigh } \\
\text { Changes }(\%)\end{array}$} \\
\hline & & $\begin{array}{c}\text { Before } \\
\text { Treatment }\end{array}$ & $\begin{array}{c}\text { After } \\
\text { Treatment }\end{array}$ & \\
\hline \multirow[t]{2}{*}{ Male } & With methanol extract of Plumeria rubra leaves & 106.00 & $111.33^{*}$ & $5.05_{\mathrm{ns}}$ \\
\hline & Without methanol extract of Plumeria rubra leaves & 119.67 & $127.00^{*}$ & 6.18 \\
\hline \multirow[t]{2}{*}{ Female } & With methanol extract of Plumeria rubra leaves & 113.00 & $121.00^{*}$ & $7.03_{\mathrm{ns}}$ \\
\hline & Without methanol extract of Plumeria rubra leaves & 111.00 & $117.00^{*}$ & 5.46 \\
\hline
\end{tabular}

(*) indicates a significant difference between before and after treatment on body weight and between treatments on body weight changes. ${ }^{*} \mathrm{P}<0.05=$ significant, ${ }^{* *} \mathrm{P}<0.001=$ highly significant, according to Paired Sample T-Test and Independent Sample T-Test, respectively $(\alpha=0.05)$. 

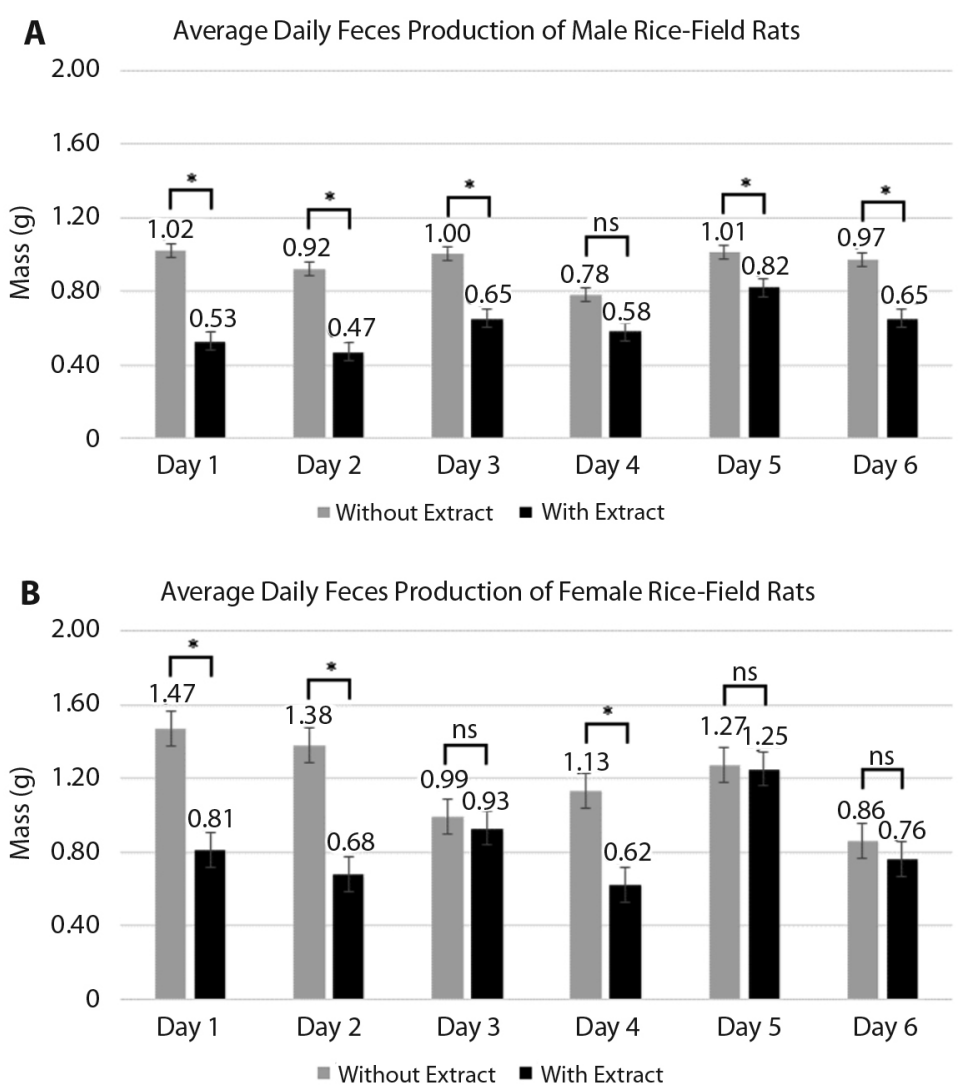

Fig. 7. Average daily feces production of male A. and female B. rice-field rats, every day until six days observation in metabolic cage. Treatments were including with and without methanol extract of Plumeria rubra leaves. Standard error (SE) of the mean is shown by a vertical bar. $(*)$ indicate a significant difference between treatments. $* \mathrm{P}<0.05=$ significant, $* * \mathrm{P}$ $<0.001=$ highly significant, according to Independent Sample T-Test $(\alpha=0.05)$.

of both male and female rice-field rats $(\mathrm{P}<$ $0.05)$. Otherwise, in accord with the Independent Sample T-test on the average body weight changes, showed that there was no-significant difference result between treatments $(\mathrm{P}<0.05)$. However, the average of temperature $30.0{ }^{\circ} \mathrm{C}$ and humidity $75.3 \%$ during the experiment at the Laboratory incompatible with optimal temperature and humidity $\left(24-26^{\circ} \mathrm{C}\right.$ and $\left.40-70 \%\right)$.

\section{Daily Activity Patterns of in Metabolic}

Cage: The treatment of methanol extract of frangipani leaves caused daily activity patterns disorder on both male and female rice-field rats (Fig. 9). The results suggested that comparing between treatments (with and without methanol extract of frangipani leaves in the metabolic cage), both male and female rice-field rats were affected daily in their activity patterns such as locomotion, foraging, and nesting activity. According to Independent Sample T-Test, extract frangipani leaves showed a significant difference for locomotion and foraging activity, yet non-significant difference to nesting activity.

\section{DISCUSSION}

Daily food and water consumption in the T-maze arena: The result showed that the food and water placed inside the control room (B) were highly significantly consumed than 

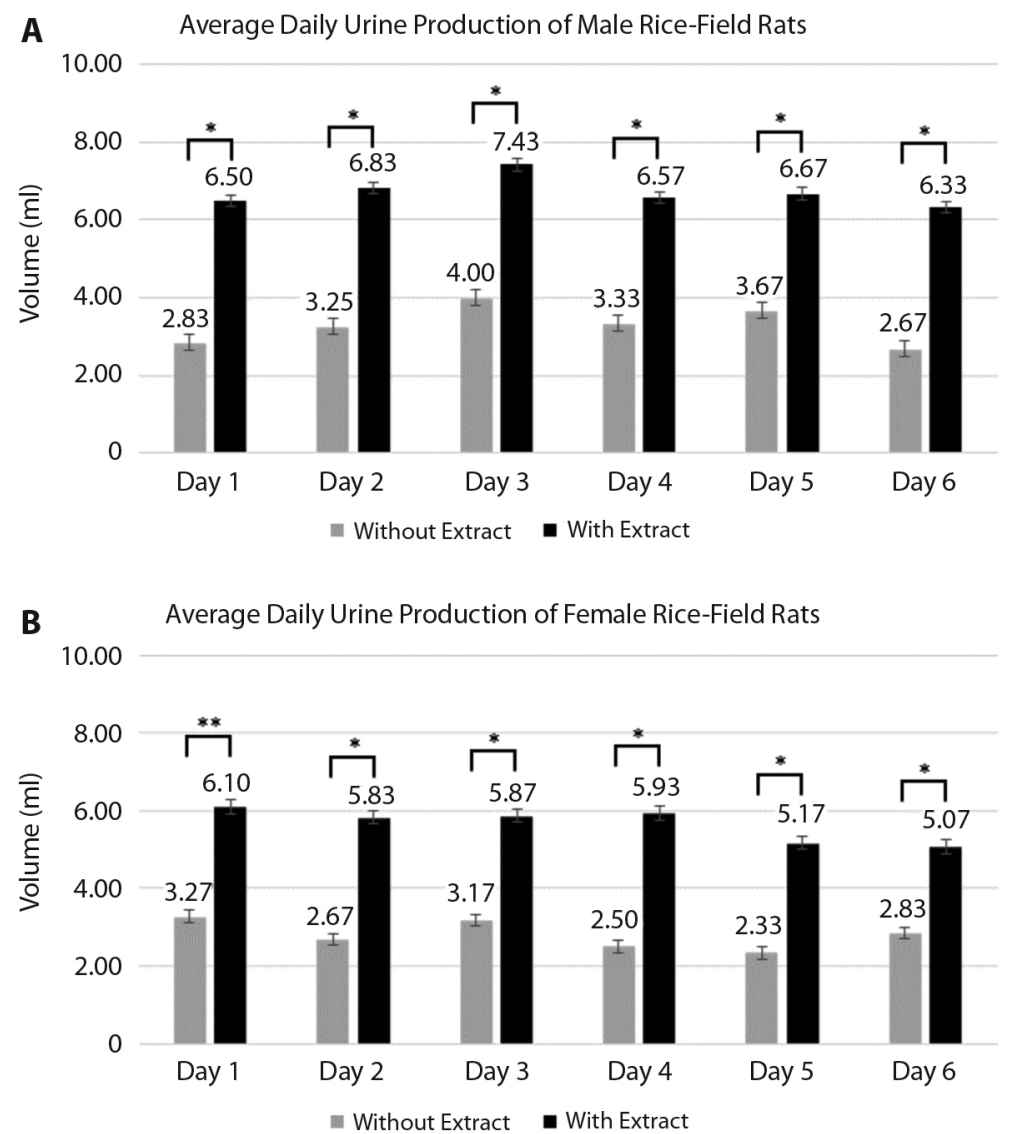

Fig. 8. Average daily feces production of male A. and female B. rice-field rats, every day until six days observation in the metabolic cage. Treatments were including with and without methanol extract of Plumeria rubra leaves. The standard error (SE) of the mean is shown by a vertical bar. $(*)$ indicates a significant difference between treatments. $* \mathrm{P}<0.05=$ significant, $* * \mathrm{P}<0.001=$ highly significant, according to Independent Sample T-Test $(\alpha=0.05)$.

inside the treatment room (A). The average daily food and water consumption of male and female rice-field rats in the T-maze arena are summarized in Fig. 3 and Fig. 4, respectively.

The Effects of Methanol Extract of Frangipani Leaves on Rice-field Rat in T-maze Arena: The methanol extract of frangipani leaves that are placed inside the treatment room may contribute as a repellent which caused that rice-field rats avoided to consume food and water that are close to the treatment. This suggestion is supported by Werner et al., (2016); wild mammals tend to change their behavioral responses, by avoiding their food that has been treated with chemical repellent. In this case, alkaloids and terpenoids that already contained in methanol extracts of frangipani leaves, reported by Manisha and Aher (2016) and Utami (2017), may be contributing to the effect, these chemical compounds have been known to be potential as a repellent material for rodents (Hansen et al., 2016).

It was found previously that both male and female rice-field rats in the T-maze arena were less to consume food and water. These results and due to the spacious space of the arena may be attributed to the average body weight loss. The effects may also have occurred because the temperature and humidity of the experimental 


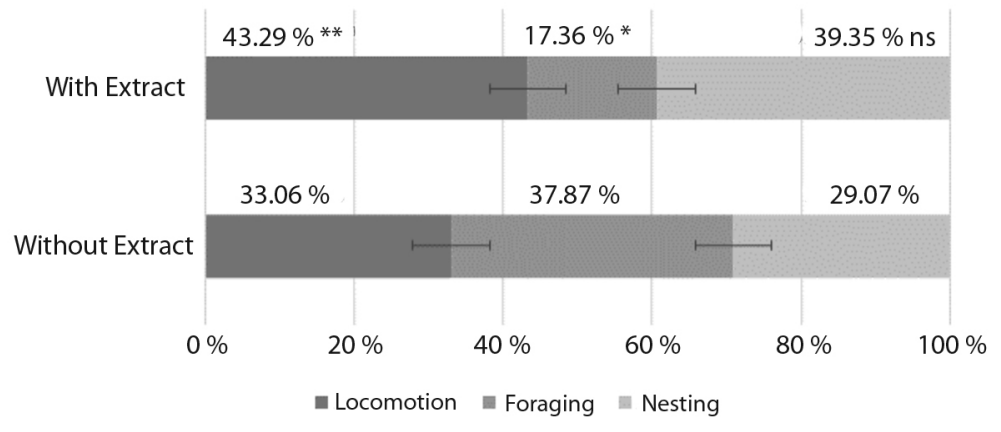

B Average Percentage of Time on Daily Activity Patterns of Female Rice-Field Rats

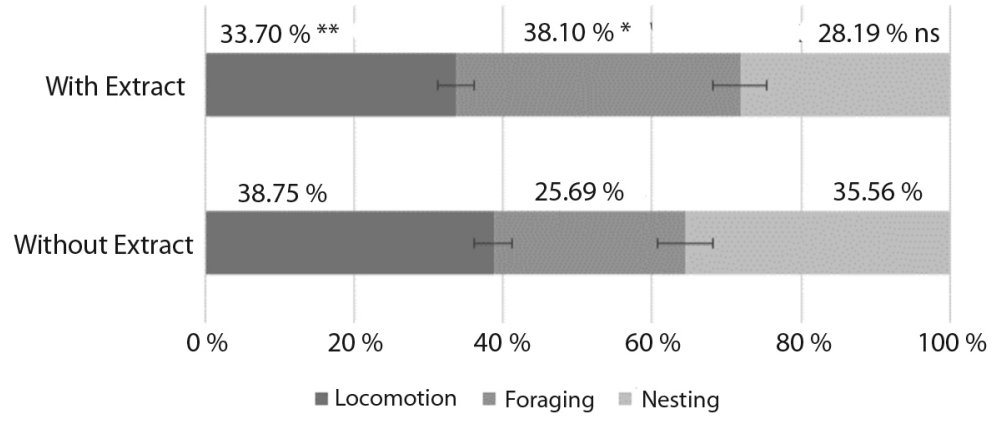

Fig. 9. The average percentage of time on daily activity patterns of male A. and female B. rice-field rats, every day until six days of observation in the metabolic cage. Treatments were including with and without methanol extract of Plumeria rubra leaves. The standard error (SE) of the mean is shown by a vertical bar. $\left(^{*}\right)$ indicates a significant difference between treatments. ${ }^{*} \mathrm{P}<0.05=$ significant, ${ }^{*} * \mathrm{P}<0.001=$ highly significant, according to Independent Sample T-Test $(\alpha=0.05)$.

environment were not suitable for the animal test. According to Richmond, Morton, and Hawkins (2007), environmental temperature and humidity can affect the health and behavior of rats.

The Effects of Methanol Extract of Frangipani Leaves on Metabolism and Daily Activity Patterns of Rice-field Rat in Metabolic Cage: In this study, we also found that rice-field rats continued to eat, either with or without methanol extract of frangipani leaves in the metabolic cage (no-choice test). It is important to note that the repellent effect by feeding the experiment will be more visible in the choice test but not in the no-choice test.
This suggestion is supported by Hansen et al. (2016), due to the unavailability of alternative food sources in the no-choice test, the animal test will adapt slowly by eating food that already exists rather than starving, although it may be hazardous. These results could be caused by the treatment and might be induced by the secondary metabolites compounds in it, such as alkaloids and terpenoids; those have been reported by Hansen et al. (2016) to be potential as rodent repellent materials. These compounds may also evaporate in the metabolic cage and give excessive thirst anxiety on the rice-field rat.

The study in metabolic cage methanol extract of frangipani leaves showed that both 
male and female rice-field rats produced highly significant of urine than without extract (control) by the difference between 2.24-3.67 ml. According to Kurien, Everds, and Scofield (2004), collecting feces and urine of the animal test are an important step in the analyses of different metabolites and toxic products. However, the only method that can be used to collect feces and urine for 24 hours with controlling over food and drink consumption of the animal test is by using a metabolic cage, although this type of housing can become a stressful environment for animals (Tarland, 2007).

The methanol extract of frangipani leaves in a metabolic cage may accidentally be eaten by the animal test and contribute to the production of urine. This suggestion is supported by Ellepola, Deraniyagala, Ratnasooriya, and Perera (2015) and also Nurjanah, Samsuar, Nopiyansah, Lande, and Kanedi (2017), the amount of urine production in rats increased after the treatment of extract of Flueggea leucopyrus and ethanol extract of Euphorbia hirta, respectively by mixing it with the animal test drinking waters. This effect is thought to be related to several plant secondary metabolites disrupt of urine output (diuretics), including saponins, tannins, flavonoids, phenols, anthraquinones, alkaloids, and deoxysugar. Nevertheless, further analyses of the hormones corticosterone and immunoglobulin $\mathrm{A}(\operatorname{Ig} \mathrm{A})$ in feces and urine samples of rats need to be done to determine the level of stress and disruption of the animal test (Hunt \& Hambly, 2006).

The body weight enhancement of male and female rice-field rats may be caused by the amount of food and water consumption that almost suitable with standard, according to Priyambodo (2009). Not only caused by the amount of food and water, but the bodyweight enhancement may also be affected due to the limited space of the housing arena.

Tahara, Aoyama, and Shibata (2017) have previously reported that behavioral changes in mammals are a physiological process that also depends on external environmental cues, including light/dark cycles, food intake, stress, and exercise. In this case, a housing rat in a metabolic cage can be a stressor. This type of housing may be commonly used for testing animals at the laboratory. However, this environment can affect behavioral changes that may lead to a negative emotional state such as causing stress in animals (Whittaker, Lymn, \& Howarth, 2016).

Both male and female rice-field rats tend to spend more time on locomotion besides other activities. In contrast to this study result, Whittaker et al., (2016) reported that in a metabolic cage, rats will spend less time moving (locomotion). These results indicate that the methanol extract of frangipani leaves also may be causing stress for the animal test. Nevertheless, a combination of metabolic cage housing and the treatment would be assumed to become an extreme stressor that can change daily activity patterns for both male and female rice-field rats.

Overall, the methanol extract of frangipani leaves affects as a repellent and caused metabolic and daily activity patterns disorder of rice-field rats. Further research is required to identify and confirm the chemical compounds in methanol extract of frangipani leaves that responsible for all the effects. The repellent application strategies by using these plant materials must be explored more in order to incorporate into a pest management program.

Ethical statement: authors declare that they all agree with this publication and made significant contributions; that there is no conflict of interest of any kind; and that we followed all pertinent ethical and legal procedures and requirements. All financial sources are fully and clearly stated in the acknowledgements section. A signed document has been filed in the journal archives.

\section{ACKNOWLEDGMENTS}

Unpad internal grant provided funding for this study. So, we would like to convey our gratitude to Sudarjat as Dean of the Faculty of Agriculture, Universitas Padjadjaran. This research partly used laboratory resources under 
a collaborative research project with the Laboratory of Rats at the Indonesian Center for Rice Research. Last, we want to give many thanks to all the members of the Laboratory of Pests, Division of Pests Vertebrate, Department of Plant Pests and Diseases, Faculty of Agriculture, Universitas Padjadjaran for their support and assistance during the experiments.

\section{RESUMEN}

Efecto del extracto foliar de Plumeria rubra (Apocynaceae), repelente de la rata (Rattus argentiventer), en su metabolismo y actividad diaria. Introducción: Las ratas arroceras son una de las plagas más importantes porque pueden producir grandes pérdidas en todas las temporadas de siembra, incluso en el almacenaje. La técnica química más utilizada para controlar las ratas de los arrozales es el raticida sintético. Sin embargo, la aplicación de estos químicos provoca indirectamente impactos negativos, por ejemplo, en el ambiente. Una alternativa para controlar la rata arrocera es la utilización de compuestos naturales como repelentes. Objetivo: Examinar los efectos del extracto metanólico de hojas de Plumeria rubra sobre el metabolismo, los patrones de actividad diaria en las ratas arroceras y su potencial como repelente. Métodos: Los experimentos se llevaron a cabo en Laboratory of Pests, Universitas Padjadjaran usando la prueba T-maze arena, y en Laboratory of Rats, Indonesian Center for Rice Research usando la prueba metabolic cage, desde febrero hasta mayo 2019. Las observaciones incluyeron consumo de alimentos $(\mathrm{g})$, consumo de agua $(\mathrm{ml})$, producción de heces $(\mathrm{g})$, producción de orina $(\mathrm{ml})$, peso corporal $(\mathrm{g})$ y cambios (\%), además actividades diarias (tiempo dedicado a la locomoción, búsqueda de alimento, y reposo). El tratamiento se realizó con tres repeticiones para 12 machos maduros y 12 hembras maduras no gestantes. Los análisis de experimentos de datos se realizaron con la prueba $\mathrm{T}$. Resultados: Las ratas arroceras en la T-maze arena evitaron consumir alimentos y bebidas cercanos al extracto de metanol de hojas de Plumeria rubra. El tratamiento del extracto metanólico de hojas de Plumeria rubra en la prueba metabolic cage provocó un trastorno metabólico en estas ratas, lo cual se demostró significativamente en la disminución del consumo promedio de alimento en $2.28 \mathrm{~g}$ y la excreción de heces en 0.34 g, además en el aumento del consumo promedio de bebida en $3.89 \mathrm{ml}$, excreción de orina en $3.15 \mathrm{ml}$ y peso corporal en $6.67 \mathrm{~g}$. El tratamiento también provocó un trastorno en los patrones de actividad diaria de las ratas, lo cual fue demostrado por el aumento significativo en el porcentaje promedio de tiempo para actividades de movimiento (locomoción) en un $7.64 \%$ y la disminución del tiempo para comer y beber (búsqueda de alimento) en un $16.46 \%$. Conclusión: El extracto metanólico de hojas de Plumeria rubra tiene un efecto repelente en las ratas arroceras.

Palabras clave: metabolitos secundarios; control químico; vertebrados; Apocynaceae; T-maze; frangipani.

\section{REFERENCES}

Brown, P.R., Leung, L.K.P., Sudarmaji, \& Singleton, G.R. (2003). Movements of the ricefield rat, Rattus argentiventer, near a trap-barrier system in rice crops in West Java, Indonesia. International Journal of Pest Management, 49(2), 123-129.

Criley, R.A. (2005). Plumeria in Hawai'i. Mänoa, USA: College of Tropical Agriculture and Human Resources, University of Hawai'i Press.

Ellepola, N., Deraniyagala, S., Ratnasooriya, W., \& Perera, K. (2015). Aqueous extract of Flueggea leucopyrus increases urine output in rats. Tropical Journal of Pharmaceutical Research, 14(1), 95-101.

Hansen, S.C., Stolter, C., Imholt, C., \& Jacob, J. (2016). Plant secondary metabolites as rodent repellents: a systematic review. Journal of Chemical Ecology, 42(9), 970-983.

Hunt, C., \& Hambly, C. (2006). Faecal corticosterone concentrations indicate that separately housed male mice are not more stressed than group housed males. Physiology and Behavior, 87(3), 519-526.

Kurien, B.T., Everds, N.E., \& Scofield, R.H. (2004). Experimental animal urine collection: A review. Laboratory Animals, 38(4), 333-361.

Manisha, K., \& Aher, A.N. (2016). Review on traditional medicinal plant: Plumeria rubra. Journal of Medicinal Plants Studies, 4(6), 204-207.

Muthusamy, K. (2014). Combustible incense of frangipani flower (Plumeria rubra) as Aedes aegypti mosquito repellent (Thesis). Gadjah Mada University, Yogyakarta, Indonesia.

Nurjanah, S., Samsuar, Nopiyansah, Lande, M.L., \& Kanedi, M. (2017). Diuretic activity of plant extract of garden spruge (Euphorbia hirata L.) on male wistar rats. European Journal of Biomedical and Pharmaceutical Science, 4(01), 516-519.

Priyambodo, S. (2009). Rice-field rat. Pengendalian Hama Tikus Terpadu (4 $4^{\text {th }}$ edition). East Jakarta, Indonesia: Penebar Swadaya.

Ramos, M.V., Araújo, E.S., Oliveira, R.S., Teixeira, F.M., Pereira, D.A., Cavalheiro, M.G., ... de Freitas, C.D. 
(2011). Latex fluids are endowed with insect repellent activity not specifically related to their proteins or volatile substances. Brazilian Journal of Plant Physiology, 23(1), 57-66.

Richmond, J., Morton, D., \& Hawkins, P. (2007). Guideline 20: Guidelines for the Housing of Rats in Scientific Institutions. Orange, Australia: Animal Research Review Panel.

Sudarmaji. (2018). Rice-field rat: Bioecology and Control. Jakarta, Indonesia: Agricultural Research and Development Agency.

Tahara, Y., Aoyama, S., \& Shibata, S. (2017). The mammalian circadian clock and its entrainment by stress and exercise. Journal of Physiological Sciences, 67(1), 1-10.
Tarland, E. (2007). Effect of metabolic cage housing on rodent welfare. Department of Clinical Sciences, 94, $557-572$.

Utami, I.W. (2017). Potensi ekstrak daun kamboja sebagai insektisida terhadap nyamuk Aedes aegypti. Higei, Journal of Public Health Research and Development, 1(1), 22-28

Werner, S.J., De Liberto, S.T., Baldwin, R.A., \& Witmer, G.W. (2016). Repellent application strategy for wild rodents and cottontail rabbits. Applied Animal Behaviour Science, 185, 95-102.

Whittaker, A.L., Lymn, K.A., \& Howarth, G.S. (2016). Effects of metabolic cage housing on rat behavior and performance in the social interaction test. Journal of Applied Animal Welfare Science, 19(4), 363-374. 